
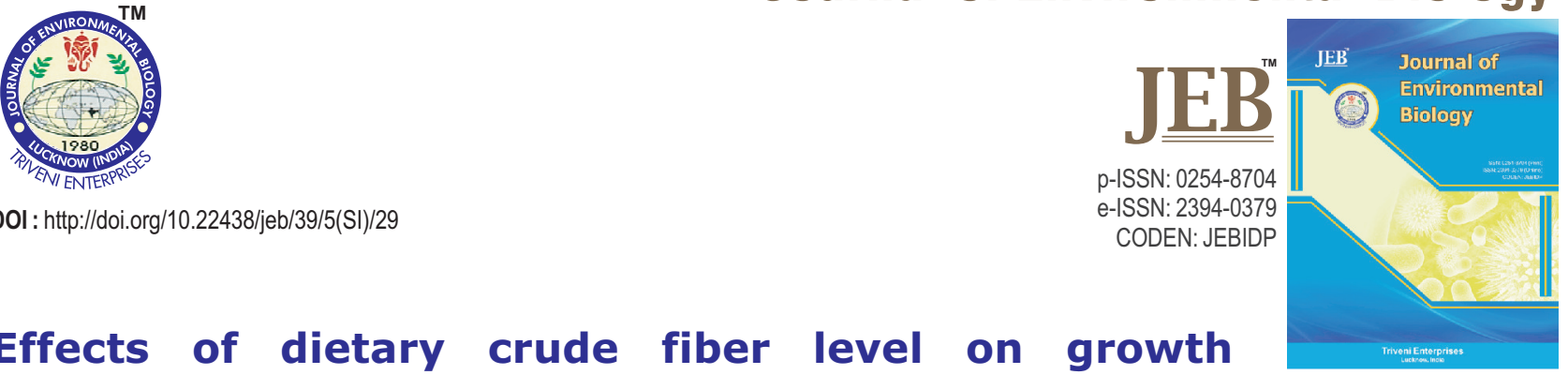

\title{
Effects of dietary crude fiber level on growth performance, body composition, liver glycogen and intestinal short chain fatty acids of a tropical carp (Barbonymus gonionotus 우 X Hypsibarbus wetmorei male ð)
}

\section{Authors Info \\ Mohd. S. Kamarudin, Muhammad A. Sulaiman* and Mohd. F.S. Ismail \\ Department of Aquaculture, Faculty of Agriculture, Universiti Putra Malaysia, 43400 UPM Serdang, Malaysia \\ ${ }^{*}$ Corresponding Author Email sulaimanbc@yahoo.co.in}

Key words

Body composition

Dietary fiber

Growth performance

Intestinal short chain fatty acids

Lemon fin barb hybrid

Publication Info

Paper received : 05.07.2017

Revised received : 20.09.2017

Re-revised received : 02.11.2017

Accepted : 28.12.2017

\begin{abstract}
Aim : A 60-day feeding trial was conducted to determine the maximum dietary crude fiber level a tropical carp, lemon fin barb hybrid, could tolerate in their diet.

Methodology : Twenty fish $(1.50 \pm 0.05 \mathrm{~g})$ were randomly stocked per 100 I aquarium tank in 3 replicates and fed twice a day with 5 isonitrogenous ( $30 \%$ protein), isocaloric $\left(17 \mathrm{~kJ} \mathrm{~g}^{-1}\right), 35 \%$ carbohydrate and isolipidic (4\%) test diets containing $0,5,10,15$ and $20 \%$ crude fiber until apparent satiation.

Results : The survival (100\%) was unaffected by the dietary fiber level although weight gain, specific growth rate, and protein efficiency ratio significantly decreased $(p<0.05)$ as dietary fiber level increased. The best feed conversion ratio (1.52) was achieved at $5 \%$ fiber level, while the protein retention increased upto $5 \%$ fiber level and decreased beyond this level. Whole body lipid significantly decreased $(p<0.05)$ with increasing dietary fiber level, whereas the body carbohydrate showed an opposite trend. No significant difference was found to the intestinal butyric acid, although acetic acid and propionic acid were higher in fish fed $0-10 \%$ crude fiber.
\end{abstract}

Interpretation : Using a second order polynomial regression analysis, the recommended dietary fiber level for the hybrid was estimated at $5.2 \%$ based on specific growth rate, which corresponded to a gross energy requirement of $17 \mathrm{~kJ} \mathrm{~g}^{-1}$. It was concluded that the hybrid fingerlings could tolerate and utilise up to $10 \%$ dietary fiber at a total carbohydrate level of $35 \%$.

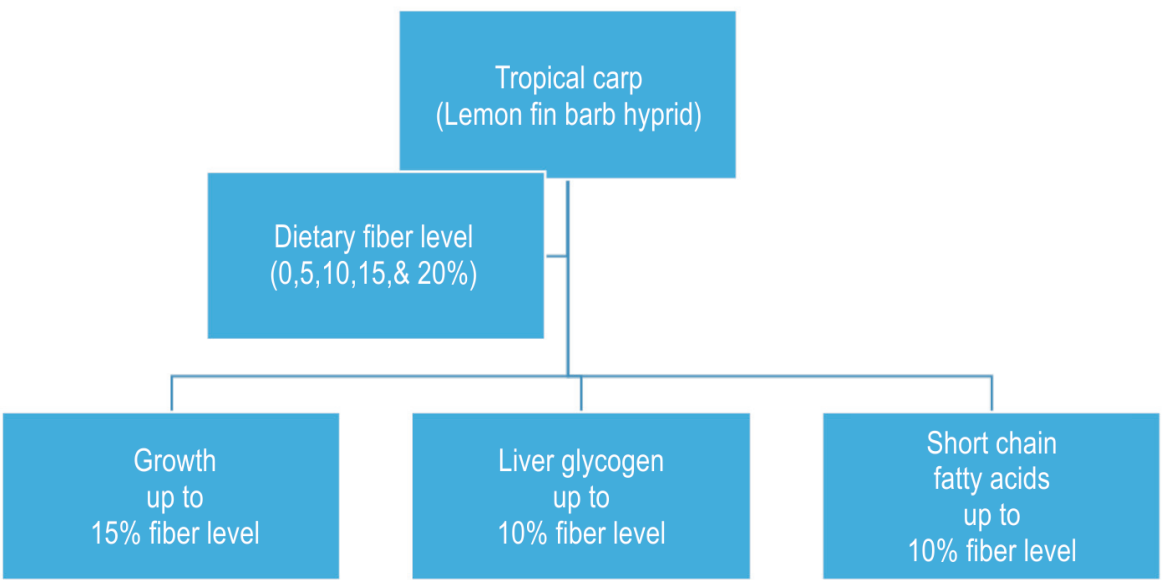




\section{Introduction}

Foods containing carbohydrates and dietary fiber make up a major component of a healthy, balanced diet in humans. High fiber intakes are associated with improved gastrointestinal function, lower risk of heart disease, rapid weight loss, reduced blood pressure, and reduced risk of certain types of cancer and lower serum cholesterol concentrations (Anderson et al., 1994). Fiber can be classified into two categories: water soluble fiber (some fruits, oat products and vegetables among others). Most plants are excellent source of insoluble fiber (Anderson et al., 1994).

Generally, the importance of proper fiber ratio of feed and its nutritional effects, digestion and metabolism, has been neglected in fish nutrition. Most researchers believe it has negative effects when incorporated in the diet (Wilson, 1995; Tripathi and Mishra, 2007), however in appropriate ratio, its effects can be as important as those of the commercial prebiotics currently applied as promoters of the development of beneficial microorganisms in the digestive system, which help positively on feed utilisation by the fish (Montagne et al., 2003; Cummings et al., 2004. Eshaghzadeh et al., 2015). Yarahmadi et al. (2014) successfully demonstrated the potential of including fiber sources in the fish feeds and suggested that its benefits in optimising fish performance and immune response shall be explored.

The generic name fiber refers to all indigestible plant matter such as celluloses, lignins and other indigestible complex carbohydrates (Leary and Lovell, 1975). A problem in the development of complete artificial diets for aquaculture is high protein requirement of many species of fish since this component contributes a high amount of the feed cost. Stone (2003) outlined the possibility of substituting expensive ingredients like fishmeal in the feed with lower cost plant protein sources such as meals of groundnut, soya bean, sunflower seed, rapeseed and cottonseed with different fiber levels. An alternative approach is to serve protein in the diet with less expensive ingredients such as lipids and carbohydrates (Anderson et al., 1984), but there is a limit to the amount of fiber that can be tolerated and this depends largely on the species of fish. Buhler and Halver (1961) observed a depressed growth in Chinook salmon reared on diets with increasing levels of a-cellulose. Leary and Lovell (1975) also noticed a growth depression among channel catfish fed $8 \%$ or more cellulose. Carnivorous species (e.g. salmonids) develop high levels of liver glycogen and suffer mortality when fed an excess of carbohydrate (Beamish et al., 1986). In contrast, omnivorous and herbivorous species such as catfish and carp appear more able to use dietary carbohydrate as an energy source (Kamalam et al., 2017).

In an effort to reduce feeding costs, carp farmers in Malaysia feed their fish with catfish or tilapia commercial diet and supplement with aquatic plant cuttings or napier grass. In this study, lemon fin barb hybrid was used as the test tropical carp and no specific commercial feed for this hybrid has been developed. The hybrid was developed in 2004 by crossing female Barbynomus gonionotus and male Hypsibarbus wetmorei. Recent research showed that the hybrid can optimally utilise $33.5 \%$ starch (Sulaiman et al., 2017). The optimal dietary protein and requirement of the hybrid are 4\% lipid (Ismail et al., 2016) and $30 \%$ protein (Suharmili et al., 2015). However, the role of fiberstarch ratio in the diet of lemon fin barb hybrids has not been published. The present study was conducted to determine the effect of dietary starch-fiber ratio on survival, growth and feeding efficiency of barb hybrid. The whole body proximate composition, intestinal short chain fatty acids and liver glycogen of these fish were also measured to better understand the role of dietary fiberstarch ratio in this fish.

\section{Materials and Methods}

Experimental diets : Five isocaloric $\left(17 \mathrm{~kJ} \mathrm{~g}^{-1}\right)$, isonitrogenous (30\% protein), isolipidic $(4 \%)$ and carbohydrate $(35 \%)$ diets containing increasing levels of cellulose fiber $(0,5,10,15$ and $20 \%$ ) were formulated and tried (Table 1). Using a single screw extruder (Brabender KE-19) with a $3 \mathrm{~mm} \varnothing$ die and barrel temperatures were set at 90,110 , and $120^{\circ} \mathrm{C}$, while the die head temperature was $135^{\circ} \mathrm{C}$ when the diets were processsed. The test diets were broken into $1 \mathrm{~mm}$ crumbles and stored airtight in plastic bags at $-20^{\circ} \mathrm{C}$ until 60 days feeding trial after the pellets were oven dried at $50^{\circ} \mathrm{C}$ for $12 \mathrm{hr}$ (Mohanta et al., 2009).

Feeding trial : Tropical carp juveniles (F1 hybrid broodstock of $H$. wetmorei $\times$ B. gonionotus) fingerlings were obtained from Perlok Aquaculture Extension Centre, Jerantut Pahang, Malaysia. The fingerlings $(1.0 \pm 0.05 \mathrm{~g})$ were then acclimatised in a $1000 \mathrm{I}$ tank for 2 weeks and fed $32 \%$ crude protein commercial tilapia diet (Star Feed (M) Sdn. Bhd., Malaysia). Tap water used was dechlorinated and vigorously aerated. The experiment was subjected to indoor natural temperature and photoperiod, respectively. On $15^{\text {th }}$ day, a total of 300 fish were equally distributed into fifteen 100 I glass aquaria. The test diets were randomly assigned to the aquaria in triplicates. The fish were fed twice daily at 09:00 am and 04:00 pm to apparent satiation. Every 15 days, the fish were bulk weighed to minimise fish stress (Wu et al., 2016).

Water quality parameters including dissolved oxygen, water temperature, $\mathrm{pH}$ and total ammonia were measured on each non-sampling days, and approximately $50 \%$ of the water was exchanged according to Kamarudin et al. (2011). Throughout the experiment, dissolved oxygen $7.5-7.8 \mathrm{mg} \mathrm{l}^{-1}, \mathrm{pH} 7.1-7.5$, water temperature ranged $28.2-29.6^{\circ} \mathrm{C}$ and ammonia-nitrogen of 0.01 $1.14 \mathrm{mg} \mathrm{l}^{-1}$. After 60 days, the fish in each tank were individually measured for final body weight gain and length. The specific growth rate (SGR) was also calculated. The protein efficiency ratio (PER), feed conversion ratio (FCR), viserosomatic index 
Table 1: Feed composition (\% as fed basis) of the experimental diets containing varying levels of fiber

\begin{tabular}{|c|c|c|c|c|c|}
\hline \multirow[t]{2}{*}{ Ingredient } & \multicolumn{5}{|c|}{ Fiber level (\% diet) } \\
\hline & 0 & 5 & 10 & 15 & 20 \\
\hline Fishmeal $^{1}$ & 59 & 59 & 59 & 59 & 59 \\
\hline Crude Palm oil $^{2}$ & 4 & 4 & 4 & 4 & 4 \\
\hline Vitamin premix ${ }^{3}$ & 1 & 1 & 1 & 1 & 1 \\
\hline Mineral premix ${ }^{4}$ & 1 & 1 & 1 & 1 & 1 \\
\hline Tapioca starch $^{5}$ & 35 & 30 & 25 & 20 & 15 \\
\hline a-cellulose ${ }^{6}$ & 0 & 5 & 10 & 15 & 20 \\
\hline \multicolumn{6}{|l|}{ Proximate composition } \\
\hline Moisture & $8.5 \pm 0.30$ & $8.8 \pm 0.36$ & $8.6 \pm 0.40$ & $8.7 \pm 0.26$ & $8.7 \pm 0.20$ \\
\hline Crude protein & $30.29 \pm 0.58$ & $30.21 \pm 0.77$ & $30.23 \pm 0.78$ & $30.14 \pm 0.25$ & $30.96 \pm 0.46$ \\
\hline Crude lipid & $4.22 \pm 0.11$ & $4.31 \pm 0.10$ & $4.24 \pm 0.11$ & $4.18 \pm 0.08$ & $4.12 \pm 0.09$ \\
\hline Crude ash & $7.12 \pm 0.16$ & $7.18 \pm 0.37$ & $7.21 \pm 0.08$ & $7.35 \pm 0.17$ & $7.47 \pm 0.12$ \\
\hline Crude fiber & $1.22 \pm 0.09$ & $6.11 \pm 0.04$ & $10.17 \pm 0.06$ & $13.88 \pm 0.02$ & $16.97 \pm 0.01$ \\
\hline Nitrogen free extract & 48.65 & 43.39 & 39.55 & 35.75 & 31.78 \\
\hline Gross energy $\left(\mathrm{kJ} \mathrm{g}^{-1}\right)$ & $17.12 \pm 0.26$ & $17.08 \pm 0.13$ & $17.04 \pm 0.12$ & $16.99 \pm 0.11$ & $17.08 \pm 0.14$ \\
\hline
\end{tabular}

${ }^{1}$ Fishmeal (local mixed species) with a dry matter, crude protein, and crude lipid at 93.4,55.8, and $5.2 \%$ as fed basis, respectively; ${ }^{2} V_{\text {itamin }}$ premix $\left(\mathrm{g} \mathrm{kg}{ }^{-1}\right.$ premix): ascorbic acid, 45; myo-inositol, 5; choline chloride, 75; niacin, 4.5; riboflavin, 1; pyridoxine, 1; thiamin mononitrate, 0.9; Ca pantothenate, 3; retinyl acetate, 0.6 ; cholecalciferol, 0.08 ; vitamin $\mathrm{K}$ menadione, 1.7 ; a-tocopheryl acetate $\left(500 \mathrm{IU} \mathrm{g}^{-1}\right), 8$; biotin, $0.02 ;$ folic acid, $0.1 ;$ vitamin $\mathrm{B}_{12}, 0.001 ;{ }^{3}$ Mineral premix (g kg-1 premix): $\mathrm{KCl}, 90 ; \mathrm{KI}, 0.04 ; \mathrm{Ca}\left(\mathrm{H}_{2} \mathrm{PO}_{4}\right) \cdot \mathrm{H} 2 \mathrm{O}, 500 ; \mathrm{NaCl}, 40 ; \mathrm{CuSO}_{4} \cdot 5 \mathrm{H}_{2} \mathrm{O}, 3 ; \mathrm{ZnSO}_{4} .7 \mathrm{H}_{2} \mathrm{O}, 4 ; \mathrm{CoSO}_{4}, 0.02 ; \mathrm{FeSO}_{4} 7 \mathrm{H}_{2} \mathrm{O}, 20$; $\mathrm{MnSO}_{4} \cdot \mathrm{H}_{2} \mathrm{O}, 3 ; \mathrm{CaCO}_{3}, 215 ; \mathrm{MgOH}, 124 ; \mathrm{Na}_{2} \mathrm{SeO}_{3}, 0.03 ; \mathrm{NaF}, 1 ;{ }^{4} \mathrm{H}_{2} \mathrm{O}$ a-cellulose was purchased from Sigma (C8002); ${ }^{5}$ nitrogen-free-extract; $\mathrm{NFE}=$ $100-$ (moisture + protein + lipid + ash + fiber)

(VSI) and hepatosomatic index (HSI) were also evaluated using the following equation.

$$
\text { Protein efficiency ratio }(P E R)=\frac{\text { Fish weight gain }(g)}{\text { Total protein intake }(g)}
$$$$
\text { Feed conversion ratio }(F C R)=\frac{\text { Total feed consumption }(g)}{\text { Fish weight gain }(g)}
$$$$
\text { Specific growth rate }\left(S G R, \% d^{-1}\right)=\frac{(\ln \text { final weight }- \text { In initial weight })}{d} \times 100
$$$$
\text { Weight gain (WG, \%) }=\frac{(\text { Final weight }- \text { Initial weight })}{\text { Initial weight }} \times 100
$$$$
\text { Survival }(\%)=\frac{\text { Initial stocking }- \text { Dead fish }}{\text { Initial stocking }} \times 100
$$$$
\text { Nutrient retention }=\frac{\text { Nutrient gain }}{\text { Nutrient intake }} \times 100
$$$$
\text { Hepatosomatic index }(\mathrm{HSI})=\frac{\text { Liver weight }}{\text { Body weight }} \times 100
$$

Viscerosomatic index $(V S I)=\frac{\text { Weight of the whole digestive tract }}{\text { Body weight }} \times 100$

Body indices : Five fish in each aquarium were euthanized with a lethal aqueous dose $\left(50 \mathrm{mg} \mathrm{l}^{-1}\right)$ of MS222 (tricaine methanesulfonate, Sigma, St. Louis, MO, USA) and weighed. The viscera that comprised intestine, intraperitoneal fat, liver and spleen were removed and weighed. The viscera weight was then divided by the weight of whole body of the hybrid and multiplied by 100 to calculate the VSI. From the same fish, the liver was then weighed, divided by the hybrid weight and multiplied by 100 to calculate the HSI according to Romano et al. (2016).

Liver histopathology : From 5 fish in each aquarium, the livers were fixed in phosphate buffered $10 \%$ (v/v) formalin for $24 \mathrm{hrs}$, followed by $70 \%$ ethanol until processing. Sections $(5 \mu \mathrm{m})$ were dehydrated, embedded in paraffin, sectioned and stained with Periodic-acid Schiff (PAS). The staining intensity was quantified according to Lee et al. (2003).

Intestinal short chain fatty acids : After storing the intestinal samples at $-20^{\circ} \mathrm{C}, 1 \mathrm{ml}$ of $20 \%$ metaphosphoric acid was added to the intestines and homogenized using a homogenizer. it was then centrifuged at 20,000 rpm for $10 \mathrm{~min}$ and the supernatant was stored at $-20^{\circ} \mathrm{C}$. Volatile fatty acids (VFA) were determined using gas-liquid chromatography with Quadrex 007 Series (Quadrex Corporation, New Haven, CT 06525, USA) bonded phase fused silica capillary column $(15 \mathrm{~m}, 0.32 \mathrm{mmID}, 0.25 \mu \mathrm{mfilm}$ 
Table 2 : Growth performance, feed utilisation and somatic indices of a tropical carp fed varying dietary crude fiber level for 60 days

\begin{tabular}{llllll}
\hline Parameter & \multicolumn{4}{c}{ Fiber level (\% diet) } \\
\cline { 2 - 5 } & 0 & 5 & 10 & 15 & 20 \\
\hline Survival (\%) & 100 & 100 & 100 & 100 & 100 \\
Initial body weight (g) & $1.55 \pm 0.14^{\mathrm{a}}$ & $1.53 \pm 0.12^{\mathrm{a}}$ & $1.54 \pm 0.06^{\mathrm{a}}$ & $1.51 \pm 0.11^{\mathrm{a}}$ & $1.51 \pm 0.12^{\mathrm{a}}$ \\
Final body weight (g) & $3.14 \pm 0.11^{\mathrm{a}}$ & $3.22 \pm 0.17^{\mathrm{a}}$ & $3.09 \pm 0.16^{\mathrm{a}}$ & $2.85 \pm 0.11^{\mathrm{ab}}$ & $2.55 \pm 0.14^{\mathrm{b}}$ \\
Body weight gain (g) & $1.59 \pm 0.06^{\mathrm{a}}$ & $1.65 \pm 0.11^{\mathrm{a}}$ & $1.55 \pm 0.09^{\mathrm{a}}$ & $1.34 \pm 0.04^{\mathrm{ab}}$ & $1.04 \pm 0.02^{\mathrm{b}}$ \\
Body weight gain (\%) & $102.58 \pm 0.21^{\mathrm{a}}$ & $107.84 \pm 0.14^{\mathrm{a}}$ & $100.65 \pm 0.15^{\mathrm{a}}$ & $88.74 \pm 0.08^{\mathrm{ab}}$ & $68.87 \pm 0.17^{\mathrm{b}}$ \\
Initial total length (cm) & $3.87 \pm 0.12^{\mathrm{a}}$ & $3.83 \pm 0.05^{\mathrm{a}}$ & $3.85 \pm 0.04^{\mathrm{a}}$ & $3.82 \pm 0.09^{\mathrm{a}}$ & $3.82 \pm 0.04^{\mathrm{a}}$ \\
Final total length (cm) & $6.30 \pm 0.09^{\mathrm{a}}$ & $6.32 \pm 0.182^{\mathrm{a}}$ & $6.28 \pm 0.02^{\mathrm{a}}$ & $6.25 \pm 0.10^{\mathrm{a}}$ & $6.17 \pm 0.01^{\mathrm{b}}$ \\
SGR (\% d) & $2.65 \pm 0.07^{\mathrm{a}}$ & $2.75 \pm 0.09^{\mathrm{a}}$ & $2.58 \pm 0.08^{\mathrm{a}}$ & $2.23 \pm 0.07^{\mathrm{ab}}$ & $1.72 \pm 0.13^{\mathrm{b}}$ \\
FCR & $1.57 \pm 0.15^{\mathrm{a}}$ & $1.52 \pm 0.21^{\mathrm{a}}$ & $1.61 \pm 0.09^{\mathrm{a}}$ & $1.87 \pm 0.14^{\mathrm{a}}$ & $2.40 \pm 0.06^{\mathrm{b}}$ \\
PER & $2.12 \pm 0.06^{\mathrm{a}}$ & $2.20 \pm 0.06^{\mathrm{a}}$ & $2.07 \pm 0.08^{\mathrm{a}}$ & $1.78 \pm 0.12^{\mathrm{ab}}$ & $1.39 \pm 0.11^{\mathrm{b}}$ \\
HSI (\%) & $1.86 \pm 0.14^{\mathrm{a}}$ & $1.88 \pm 0.19^{\mathrm{a}}$ & $1.87 \pm 0.06^{\mathrm{a}}$ & $1.84 \pm 0.22^{\mathrm{a}}$ & $1.83 \pm 0.09^{\mathrm{a}}$ \\
VSI (\%) & $8.44 \pm 0.11^{\mathrm{a}}$ & $8.43 \pm 0.14^{\mathrm{a}}$ & $8.45 \pm 0.11^{\mathrm{a}}$ & $8.41 \pm 0.021^{\mathrm{a}}$ & $8.42 \pm 0.123^{\mathrm{a}}$ \\
\hline
\end{tabular}

Values are mean $\pm S E$ of three replicates. Different superscripted letters in the same row indicate significant differences ( $p<0.05)$.WG: weight gain; $S G R$ : specific growth rate; FCR: feed conversion ratio; PER: protein efficiency ratio; HSI: hepato somatic index; VSI: visero somatic index

Table 3: Whole body proximate composition (\% wet weight basis) of a tropical carp fed varying dietary crude fiber level for 60 days

\begin{tabular}{lllllll}
\hline Component & \multicolumn{5}{l}{ Fiber level (\% diet) } \\
\cline { 2 - 7 } & Initial & 0 & 5 & 10 & 15 & 20 \\
\hline Moisture & $74.49 \pm 0.27$ & $71.20 \pm 0.13^{\mathrm{a}}$ & $71.33 \pm 0.62^{\mathrm{a}}$ & $71.25 \pm 0.54^{\mathrm{a}}$ & $72.08 \pm 0.46^{\mathrm{a}}$ & $71.82 \pm 0.69^{\mathrm{a}}$ \\
Crude protein & $14.51 \pm 0.18$ & $15.33 \pm 0.20^{\mathrm{a}}$ & $15.37 \pm 0.80^{\mathrm{a}}$ & $15.31 \pm 0.33^{\mathrm{a}}$ & $15.21 \pm 0.15^{\mathrm{a}}$ & $15.17 \pm 0.19^{\mathrm{a}}$ \\
Crude lipid & $6.04 \pm 0.11$ & $9.43 \pm 0.310^{\mathrm{a}}$ & $9.25 \pm 0.20^{\mathrm{a}}$ & $9.23 \pm 0.30^{\mathrm{a}}$ & $8.35 \pm 0.25^{\mathrm{b}}$ & $8.29 \pm 0.22^{\mathrm{b}}$ \\
Ash & $2.23 \pm 0.12$ & $1.34 \pm 0.07^{\mathrm{a}}$ & $1.33 \pm 0.09^{\mathrm{a}}$ & $1.37 \pm 0.07^{\mathrm{a}}$ & $1.34 \pm 0.09^{\mathrm{a}}$ & $1.38 \pm 0.06^{\mathrm{a}}$ \\
Crude fiber & 0.04 & $0.11 \pm 0.06^{\mathrm{a}}$ & $0.11 \pm 0.02^{\mathrm{a}}$ & $0.12 \pm 0.09^{\mathrm{a}}$ & $0.12 \pm 0.05^{\mathrm{a}}$ & $0.12 \pm 0.02^{\mathrm{a}}$ \\
Nitrogen free extract & 2.46 & $2.59^{\mathrm{b}}$ & $2.46^{\mathrm{b}}$ & $2.66^{\mathrm{b}}$ & $2.9^{\mathrm{a}}$ & $3.22^{\mathrm{a}}$ \\
Gross energy (kJ g ( $^{-1}$ & $6.77 \pm 0.8$ & $6.88 \pm 0.6^{\mathrm{a}}$ & $6.70 \pm 0.7^{\mathrm{a}}$ & $6.23 \pm 0.8^{\mathrm{ab}}$ & $6.17 \pm 0.2^{\mathrm{b}}$ & $6.13 \pm 0.4^{\mathrm{b}}$ \\
\hline
\end{tabular}

Mean values with same superscripts in each row are not significantly different $(p<0.05)$. Values are mean of three replicates of each experimental diet \pm SD

Table 4 : Protein, lipid, carbohydrate and energy retention in a tropical carp fed diets containing varying fiber level as a starch replacement ( $35 \%$ diet) for 60 days

\begin{tabular}{llllll}
\hline Retention (\%) & \multicolumn{5}{c}{ Fiber level (\% diet) } \\
\cline { 2 - 6 } & 0 & 5 & 10 & 15 & 20 \\
\hline Protein & $34.19 \pm 0.29^{\mathrm{a}}$ & $34.72 \pm 0.21^{\mathrm{a}}$ & $31.52 \pm 0.23^{\mathrm{a}}$ & $26.97 \pm 0.14^{\mathrm{b}}$ & $20.96 \pm 0.64^{\mathrm{c}}$ \\
Lipid & $134.99 \pm 0.22^{\mathrm{a}}$ & $102.38 \pm 0.13^{\mathrm{b}}$ & $95.17 \pm 0.14^{\mathrm{c}}$ & $65.73 \pm 0.17^{\mathrm{d}}$ & $56.87 \pm 0.35^{\mathrm{e}}$ \\
Carbohydrate & $3.80 \pm 0.23^{\mathrm{a}}$ & $3.46 \pm 0.14^{\mathrm{a}}$ & $4.06 \pm 0.19^{\mathrm{a}}$ & $3.62 \pm 0.11^{\mathrm{a}}$ & $3.32 \pm 0.26^{\mathrm{a}}$ \\
Energy & $54.88 \pm 0.12^{\mathrm{a}}$ & $56.16 \pm 0.15^{\mathrm{a}}$ & $52.37 \pm 0.13^{\mathrm{a}}$ & $44.73 \pm 0.19^{\mathrm{b}}$ & $39.46 \pm 0.28^{\mathrm{c}}$ \\
\hline
\end{tabular}

Mean values with same superscripts in each row are not significantly different $(p<0.05)$. Values are mean of three replicates of each experimental diet \pm SD

thickness) in an Agilent 7890 Agas liquid chromatography (Agilent Technologies, Palo Alto, CA, USA) equipped with a flame ionization detector (FID). The injector/detector temperature was programmed at $220 / 230^{\circ} \mathrm{C}$ respectively. The column temperature was set in a range of $70-50^{\circ} \mathrm{C}$ with temperature programming @ $7^{\circ} \mathrm{C} \mathrm{min}^{-1}$ increments to facilitate optimal separation. Peaks were identified by comparison with authentic standards of acetic, propionic, butyric, isobutyric, valeric, isovaleric and 4-methyl-nvaleric acids (Sigma, St. Louis, Mo., USA). An internal standard (4-methyl-n-valeric acids) was used for VFA determination according to (Kihara and Sakata, 1997).

Proximate composition : The initial whole body proximate composition of 20 fish were measured from the stock at the 


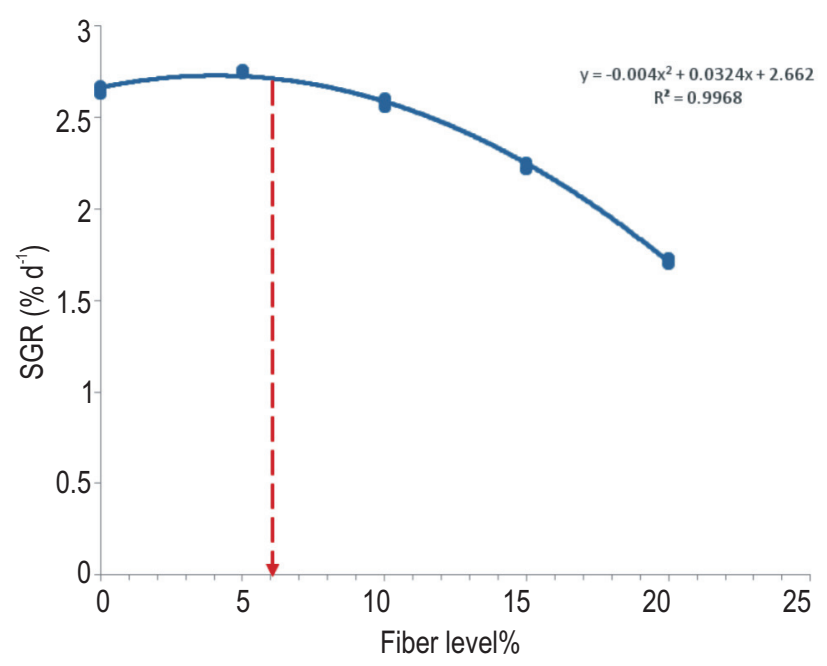

Fig. 1 : Polynomial relationship between SGR of a tropical carp and dietary fiber level

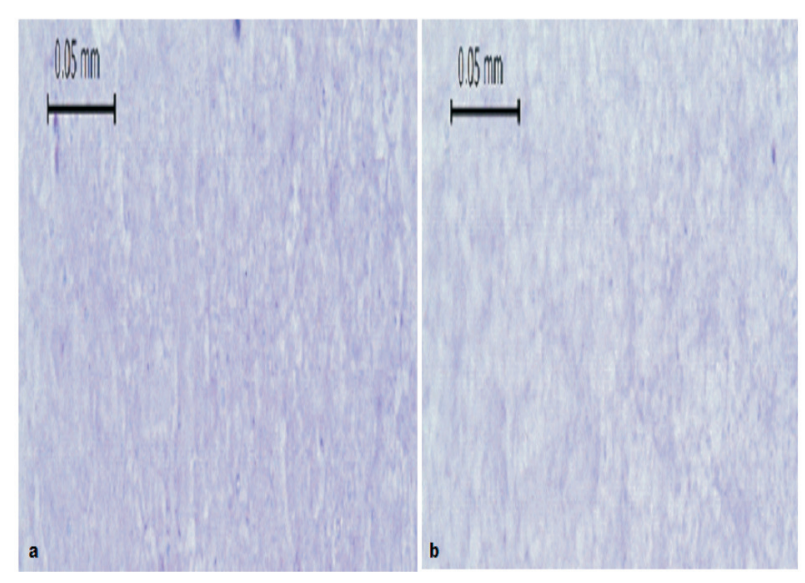

Fig. 3 : Periodic-acid Schiff (PAS) staining of liver in a tropical carp from (a) $5 \%$ and (b) $20 \%$ dietary fiber level

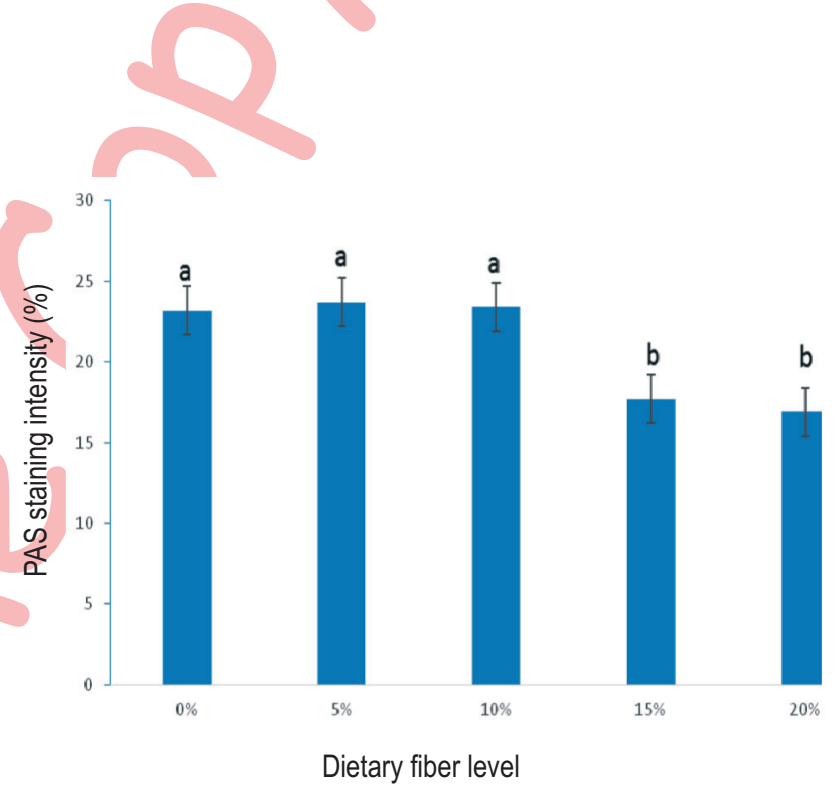

Fig. 4 : Values are mean \pm SE Periodic-acid Schiff (PAS) staining intensity in the liver of a tropical carp fed increasing fiber levels after 60 days. Differentletters indicate significant differences $(p<0.05)$

acid digestion followed by alkaline digestion (Foss Tecator Fibertec 2010 Hot Extractor). Gross energy content was determined using a bomb calorimeter (IKA C 200 Oxygen Bomb calorimeter).

Statistical analyses : All data were subjected to one-way analysis of variance (ANOVA) after prior confirmation of data homogeneity using Statistical Analysis System 9.4 for Windows (SAS Inc., USA). Percentage data were arsine transformed. Differences among dietary treatments were identified using Tukey's test and optimal growth curve was evaluated using second order polynomial regression. 


\section{Results and Discussion}

All fish survived the 60-day feeding trial. The dietary fiber level significantly affected fish growth, FCR and PER (Table 2). The fish fed $0-10 \%$ fiber exhibited significantly higher growth and PER than those fed $20 \%$ fiber $(p<0.05)$. A second order polynomial regression showed that $5.2 \%$ was the optimal inclusion level of fiber for this hybrid (Fig. 1). FCR was significantly better among fish fed $0-15 \%$ fiber than that of fish fed $20 \%$ fiber. HSI and VSI were not affected by the dietary fiber level.

The whole body proximate compositions of lemon fin barb hybrid at the beginning and end of the experiment are shown in Table 3. The results showed that the dietary fiber level had no significant effect on the moisture, crude ash or crude protein content of the fish. Increasing dietary fiber level decreased body lipid with fish fed $15-20 \%$ dietary Fiber having significantly lower body lipid than those fed 0-10\% dietary fiber. A similar trend in the body energy was observed. In contrast, body NFE was significantly higher among fish fed $15-20 \%$ fiber. The protein, energy and lipid retention by hybrid fingerlings were significantly affected by the dietary fiber level and continually decreased as dietary fiber inclusion increased (Table 4). The carbohydrate retention in the fish was low and not affected by the dietary fiber level.

The most dominant intestinal short chain fatty acid in lemon barb hybrid was acetic acid, followed by propionic acid, butyric acid and isobutyric acid (Fig. 2). The highest amount of intestinal acetic acid was found among fish fed $5 \%$ fiber which was only significantly higher from those fed $15-20 \%$ fiber. Similarly fish fed $0-10 \%$ fiber had significantly higher propionic acid than those fed $15-20 \%$ dietary fiber. No significant differences among treatments were found for intestinal isobutyric and butyric acid.

Histological examination of liver hepatocytes of the barb hybrid showed intact cellular structure and staining character of the hepatocytes in all treatments (Fig. 3). Even though the liver looked normal, the glycogen content and lipid vacuolization in hepatocytes of the liver decreased with the increase of dietary fiber level. Fish fed $5 \%$ fiber had more PAS positive material. The fish fed $0-10 \%$ fiber exhibited significantly higher periodic-acid Schiff (PAS) staining intensity than those fed $15-20 \%$ fiber (Fig. 4).

Non-digestible component in feed ingredients such as crude fiber plays an important role in fish as prebiotic to enhance intestinal microbiota and improve digestion, absorption and assimilation in the fish digestive system (Desai et al., 2012; Ingerslev et al., 2014). The growth of chinook salmon reduces with increasing dietary level of fiber (Buhler and Halver, 1961) similar to what was observed in the present study. This study also demonstrated that the tropical carp hybrid could tolerate up to $15 \%$ dietary crude fiber without affecting its growth, feed efficiency and body composition. The fish growth and feed efficiency were severely reduced when fish were fed a $20 \%$ fiber. However, a dietary fiber level of above $10 \%$ seemed to affect the dietary protein and energy retention. Anderson et al. (1984) stated that a dietary fiber level of above $10 \%$ is not recommended for the omnivorous tilapia. The growth reduction in carnivore rainbow trout fed on $10 \%$ fiber is associated with a decrease in gut passage time (GPT) and diet digestibility (Hilton and Atkinson, 1982). A growth depression has also been reported in channel catfish fed above $8 \%$ fiber (Leary and Lovell, 1975). In addition, fiber level of $8 \%$ or less in the diets of channel catfish may improve binding and water stability of pelleted diets and the fish growth rate.

Even though the hybrid liver looked normal, the glycogen content and lipid vacuolization in hepatocytes of the liver decreased with increasing dietary fiber level. No reduction of the nucleus was observed indicating degeneration of hepatocytes did not occur. This demonstrated that in general the liver was not affected by the increasing dietary fiber level which was similar to that reported in the Malaysian mahseer (Ishak et al., 2016). It is well known that cellulose is less physiologically active than other types of fiber such as lignin and pectin in altering the uptake of dietary minerals (Harmuth and Schelenz, 1980). This may explain why no damages or stress was observed in the liver of the barb hybrid throughout the feeding trail (Sulaiman et al., 2017b).

Short-chain fatty acids (SCFAs) are the by-product of fiber fermentation in the colon, particularly acetate, which improves the synthesis of cholesterol (Titus and Ahearn, 1988; Smith et al., 1996; Kihara and Sakata, 1997). Cholesterol is a precursor of hormones associated with protection against stress and vitamin D synthesis (Deng et al., 2013). The by-products from bacterial fermentation of certain starch within the digestive tract of animals can have some benefits as an energy source and biological control of pathogenic microbes (Leenhouwers et al., 2008; Romano et al., 2016).

In the current study, once the dietary fiber level reached $10 \%$, there were significant drop in the production of acetic and propionic acids. The significantly lower intestinal SCFAs when the hybrid was fed a diet with the highest amount of fiber indicated that $0-10 \%$ fiber was fermented better by intestinal microbes which produced large amount of acetic and propionic acids than $15-20 \%$ fiber. This observation is in agreement with the findings in tilapia (Kihara et al., 2002; Cuesta et al., 2007).

The inclusion of a suitable amount of fiber in a diet can minimise the use of antibiotics in animals, and thus ensures food safety (Adorian et al., 2016). Fibers such yeast autolysate and linseed have no anti-nutritional action rather provide a better performance and deposition of nutrients (Adorian et al., 2015). A good growth performance was reported when silver catfish was fed a diet containing fed a diet containing fiber (linseed bran) suggesting its growth promoting effect (Adorian et al., 2015). 
While some components of the dietary fiber are used as a substrate by intestinal bacteria, the insoluble fraction is slowly or partially fermented compared to the soluble fraction which is rapidly fermented. Any food or dietary ingredient that reaches the large intestine intact is a potential prebiotic but shall be fermented by beneficial microorganisms in order to be effectively considered as prebiotic (Lan et al., 2005).

It can be conclude that a diet containing 5-10\% fiber i.e. 30 or $25 \%$ starch a total of $35 \%$ carbohydrate with gross energy $17 \mathrm{~kJ} \mathrm{~g}^{-1}, 30 \%$ protein and $4 \%$ lipid was recommended for the culture of fingerlings tropical lemon fin barb hybrid. Further research should be done to assess the effects of feeding diets with 5 and $10 \%$ different types of fiber on the intestinal amylase and cellulose enzyme activity.

\section{Acknowledgments}

The authors would like to thank the staff from Perlok Aquaculture Extension Centre, Jerantut Pahang, Malaysia for their cooperation and fry supply. This study was funded the Ministry of Higher Education through FRGS Grant no. 07-01-151651FR.

\section{References}

Adorian, T. J., F. R. Goulart, N. de Menezes Lovatto, M. Dalcin and L. P. da Silva : Effect of different dietary fiber concentrates on the metabolism and indirect immune response in silver catfish. Animal Feed Sci. Technol., 215, 124-132 (2016).

Adorian, T. J., P. I. Mombach, F. R. Goulart, B. B. Loureiro, D. Pianesso and L. P. da Silva : Dietary fiber in the nutrition of silver catfish: Prebiotic or antinutrient? Animal Feed Sci. Technol., 209, 167-173 (2015).

Anderson, J., A.J. Jackson, A.J. Matty and B.S. Capper: Effects of dietary carbohydrate and fibre on the tilapia Oreochromis niloticus (Linn.). Aquaculture, 37, 303-314 (1984).

Beamish, F. W. H., J. W. Hilton, E. Niimi and S. J. Slinger : Dietary carbohydrate and growth, body composition and heat increment in rainbow trout (Salmo gairdneri). Fish Physiol. Biochem., 1, 85-91 (1986).

Buhler, D. R. and J. E. Halver : Nutrition of salmonoid fishes. Carbohydrate requirements of chinook salmon. J. Nutrit., 74 , 307-318 (1961).

Cuesta, A., L. Vargas-Chacoff, A. García-López, F. J. Arjona and G. Martínez-Rodríguez: Effect of sex-steroid hormones, testosterone and estradiol, on humoral immune parameters of gilthead seabream. Fish and Shellfish Immunol., 23, 693-700 (2007).

Cummings, J. H., L. M. Edmond and E. A. Magee: Dietary carbohydrates and health: Do we still need the fibre concept? Clinical Nutrit. Supple., 1, 5-17 (2004).

Daniel, F. L. and T. R. Lovell : Value of fiber in production-type diets for channel catfish. Transactions of the American Fisheries Society, 104, 669-674 (1975).

Deng, J., B. Kang, L. Tao, H. Rong and X. Zhang : Effects of dietary cholesterol on antioxidant capacity, non-specific immune response, and resistance to Aeromonas hydrophila in rainbow trout (Oncorhynchus mykiss) fed soybean meal-based diets. Fish Shellfish Immunol., 34, 324-331 (2013).

Desai, A. R., M. G. Links, S. A. Collins, G. S. Mansfield, M. D. Drew, A. G. Van Kessel and J. E. Hill : Effects of plant-based diets on the distal gut microbiome of rainbow trout (Oncorhynchus mykiss). Aquaculture, 350-353, 134-142 (2012).

Eshaghzadeh, H., S. H. Hoseinifar, H. Vahabzadeh and E. Ringø : The effects of dietary inulin on growth performances, survival and digestive enzyme activities of common carp (Cyprinus carpio) fry. Aquaculture Nutrit., 21, 242-247 (2015).

Harmuth-Hoene, A.E. and R. Schelenz : Effect of dietary fiber on mineral absorption in growing rats. J. Nutrit., 110, 1774-1784 (1980).

Hilton, J. W. and J. L. Atkinson : Response of rainbow trout (Salmo gairdneri) to increased levels of available carbohydrate in practical trout diets. British J. Nutrit., 47, 597 (1982).

Ingerslev, H. C., M. L. Strube, L. Jørgensen, G. Von, I. Dalsgaard, M. Boye and $L$. Madsen : Diet type dictates the gut microbiota and the immune response against Yersinia ruckeri in rainbow trout (Oncorhynchus mykiss). Fish Shellfish Immunol., 40, 624-633 (2014).

Ishak, S. D., M. S. Kamarudin, E. Ramezani-Fard, C. R. Saad and Y. A. Yusof : Effect of varying dietary carbohydrate level on growth performance, body composition and liver histology of Malaysian mahseer fingerlings. J. Environ. Biol., 37, 755-764 (2016).

Ismail, S., M. S. Kamarudin and C. R. Saad : Dietary lipid requirement of lemon fin barb hybrid. J. Environ. Biol., 37, 765-774 (2016).

Anderson, J. W., B. M. Smith and N. J. G. : Health benefits practical of high-fiber. American J. Clinical Nutrit., 59, 1242S-1246 (1994).

Kamalam, B. S., F. Medale and S. Panserat : Utilisation of dietary carbohydrates in farmed fishes: New insights on influencing factors, biological limitations and future strategies. Aquaculture, 467, 3-27 (2017).

Kamarudin, M. S., S. Otoi and C. R. Saad: Changes in growth, survival and digestive enzyme activities of Asian redtail catfish, Mystus nemurus, larvae fed on different diets. African J. Biotechnol., 10, 4484-4493 (2011).

Kihara, M. and T. Sakata : Fermentation of dietary carbohydrates to short-chain fatty acids by gut microbes and its influence on intestinal morphology of a detritivorous teleost tilapia (Oreochromis niloticus). Compar. Biochem. Physiol. - A Physiol., 118, 1201-1207 (1997).

Kihara, M., T. Sakata, T. B. Smith, D. H. Wahl and R. I. Mackie : Production of short-chain fatty acids and gas from various oligosaccharides by gut microbes of carp (Cyprinus carpio L.) in micro-scale batch culture. Compar. Biochem. Physiol. - A Molec. Integra. Physiol., 132, 333-340 (2002).

Lan, Y., M. Verstegen, S. Tamminga and B. A. Williams : The role of the commensal gut microbial community in broiler chickens. World's Poultry Sci. J., 61, 95-104 (2005).

Lee, S., K. Kim and S. P. Laii : Utilization of glucose, maltose, dextrin and cellulose by juvenile flounder (Paralichthys olivaceus). Aquaculture, 221, 427-438 (2003).

Leenhouwers, J. I., W. F. Pellikaan, H. F. A. Huizing, R. O. M. Coolen, J. A. J. Verreth and J. W. Schrama : Fermentability of carbohydrates in an in vitro batch culture method using inocula from Nile tilapia (Oreochromis niloticus) and European sea bass (Dicentrarchus labrax). Aquacul. Nutrit., 14, 523-532 (2008).

Mohanta, K. N., S. N. Mohanty, J. Jena, N. P. Sahu and B. Patro: Carbohydrate level in the diet of silver barb, Puntius gonionotus 
(Bleeker) fingerlings: Effect on growth, nutrient utilization and whole body composition. Aquacul. Res., 40, 927-937 (2009).

Montagne, L. Pluske and D. J. Hampson : A review of interactions between dietary fibre and the intestinal mucosa and their consequences on digestive health in young non-ruminant animals. Animal Feed Sci. Technol., 108, 95-117 (2003).

Romano, N., W. Simon, M. Ebrahimi, A. H. I. Fadel, C. M. Chon and M. S. Kamarudin : Dietary sodium citrate improved oxidative stability in red hybrid tilapia (Oreochromis sp.) but reduced growth, health status, intestinal short chain fatty acids and induced liver damage. Aquaculture, 458, 170-176 (2016).

Smith, T. B., D. H. Wahl and R. I. Mackie : Volatile fatty acids and anaerobic fermentation in temperate piscivorous and omnivorous freshwater fish. J. Fish Biol., 48, 829-841 (1996).

Stone, D. J. : Dietary carbohydrate utilization by fish. Reviews in Fisheries Sci., 11, 337-369 (2003).

Suharmili, R., M. S. Kamarudin, C. R. Saad and M. H. Mahmud : Effects of varying dietary protein level on the growth, feed efficiency and body composition of lemon fin barb hybrid fingerlings. Iranian $\mathrm{J}$. Fisheries Sci., 14, 425-435 (2015).

Sulaiman, M.A., M. S. Kamarudin and M. F. S. Ismail : The relationship between dietary carbohydrate level and the levels of blood glucose and amylase in lemon fin barb hybrid (Barbonymus gonionotus o $\mathrm{X}$ Hypsibarbus wetmorei male đ̊). ATBU, J. Sci. Technol. Educ., 5, 110-119 (2017).

Sulaiman, M. A., K. A. Fari, F. E. Osho and S. I. Ogah : Effect of partial feed deprivation on plasma total protein and glucose as stress indicators in African catfish Clarias gariepinus (Burchell 1822). ATBUJ. Sci., Technol. Educ., 5, 1-8(2017).

Titus, E. and G. A. Ahearn : Short-chain fatty acid transport in the intestine of a herbivorous teleost. J. Experi. Biol., 135, 77-94 (1988).

Torrecillas, S., D. Montero, M. J. Caballero, L. Robaina, M. J. Zamorano, J. Sweetman and M. Izquierdo: Effects of dietary concentrated mannan oligosaccharides supplementation on growth, gut mucosal immune system and liver lipid metabolism of European sea bass (Dicentrarchus labrax) juveniles. Fish and Shellfish Immunol., 42, 508-516 (2015).

Tripathi, M. K. and A. S. Mishra : Glucosinolates in animal nutrition: A review. Animal Feed Sci. Technol., 132, 1-27 (2007).

Wilson, R. P. : Lipid nutrition of finfish. In.: Nutrition and Utilization Technology in Aquaculture (Ed.: D. J. Lim and C. Sessa). AOCS Press. pp.74-81(1995).

Wu, C., J. Ye, J. Gao, X. Yang and Y. Zhang : Effect of varying carbohydrate fractions on growth, body composition, metabolic, and hormonal indices in juvenile black carp, Mylopharyngodon piceus. J. WorldAquacul. Soci., 47, 435-449 (2016).

Yarahmadi, P., H. Kolangi Miandare, H. Farahmand, A. Mirvaghefi and S. $H$. Hoseinifar : Dietary fermentable fiber upregulated immune related genes expression, increased innate immune response and resistance of rainbow trout (Oncorhynchus mykiss) against Aeromonas hydrophila. Fish Shellfish Immunol., 41, 326-31 (2014).

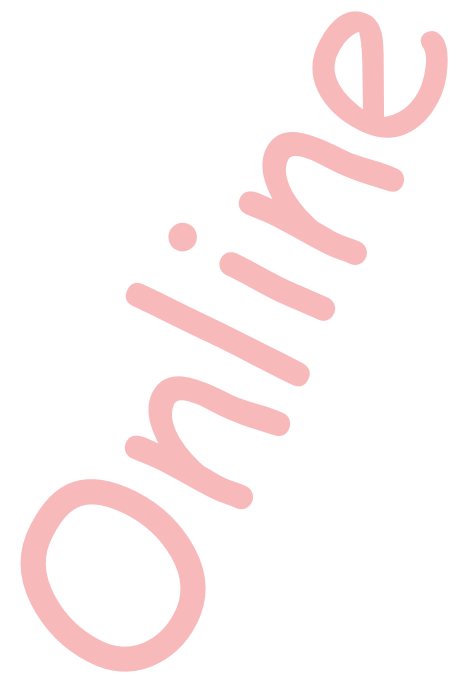

